\title{
Balancing corn stover harvest for biofuels with soil and water conservation
}

\author{
R.M. Cruse and C.G. Herndl
}

\begin{abstract}
The emerging cellulosic biofuel industry offers both challenges and opportunities for conserving soil and water resources in an agriculturally productive environment. Crop residues are North America's most important soil and water conservation resource and concurrently will be the most important feedstock for the emerging cellulosic biofuels industry. This analysis of factors affecting water-induced soil erosion, soil carbon maintenance, and water quality in the emerging cellulosic bioenergy industry identifies a variety of critical issues likely to both directly and indirectly lead to greater degradation of these resources. Pressing issues are also identified for scientific research and for policy analysis. Research should determine more precisely the erosion rates and sediment delivery rates of different biomass cropping systems, determine the acceptable rates of residue removal for different crops and soils in the face of more frequent extreme rainfall events, describe how those removal rates vary spatially across the landscape, develop the harvest technology that removes residue at these rates, and develop a suite of conservation practices appropriate for use with crop residue harvest. Policy analysis should examine land ownership and management patterns to develop a policy environment in which conservation practices are encouraged, or at least not discouraged. A framework must be developed to oversee and insure that residue removal rates are not abusive to soil and water resources.
\end{abstract}

Key words: bioenergy—soil carbon—soil erosion—water quality

Current energy price increases, greenhouse gas emissions, and security concerns over oil supplies have dramatically increased interest in biofuels, which in turn raises concerns about the potential soil and water impacts of this new industry. Biomass and various liquid fuels or biofuels derived from biomass may be a substantial source of renewable fuels suitable to replace a portion of the petroleum-based fuels consumed in the United States. According to the US Energy Information Administration (2008), the United States used 5.1 billion gasoline-equivalent gallons of biofuels in 2007, which represented a mere $3.6 \%$ of the gasoline market share. When the US Department of Energy (DOE) established its goals for future consumption of biofuels in Vision for Bioenergy and Biobased Products in the United States (US DOE Biomass Technical Advisory Committee 2002), the authors recognized continued growth in liquid fuel demand and proposed that biofuels constitute $10 \%$ of the market in 2020 , or 22.7 billion gasolineequivalent gallons. By 2030, this is proposed
Biofuel feedstock (biomass) is a renewable resource and may be relatively low cost. Biofuels are readily adaptable to current technology and needs. The use of biofuels has the potential to mitigate greenhouse warming by providing energy from a potentially carbon dioxide-neutral feedstock. Supplying biomass as feedstock for biofuel production offers the agricultural sector a method to address national security considerations by developing energy production from domestic sources. Finally, biofuel production has the potential, though certainly not the guarantee, to revitalize rural communities and their economy and social networks.

These advantages of cellulosic ethanol production and the visions of replacing a substantial amount of petroleum-derived fuel with biofuels have created expectations in government bodies interested in reducing our dependence on foreign petroleum as evidenced in the Energy Independence and Security Act of 2007, in the investment community interested in financial return of biofuels, and in rural America seeking ways to revitalize agricultural communities. However, these expectations can be met only if the developing cellulosic conversion industry is developed in such a way that it is both highly productive and sustainable. In order to maintain a continuous, targeted level of biofuel production that lasts indefinitely, the industry must preserve or improve the human, social, and natural environment, the resources upon which biofuel production depends.

Unfortunately, the production of cellulose-derived biofuels offers a number of socioeconomic and environmental challenges that must be addressed. First and foremost, the elevated levels of cellulosic feedstock that must be available to meet the goals of existing visions (Perlack et al. 2005) can be produced only if soil and water resources are not degraded, since these necessary resources are not renewable in a human life span and have no substitute. The conflict that must be managed is that the cellulosic feedstocks coming from annual crops, i.e., crop plant residues upon which the developing industry will rely, are also the same plant residues we rely upon to protect much of this nation's soil

Richard $M$. Cruse is a professor in the Department of Agronomy and Carl G. Herndl is a professor in the Department of English at lowa State University, Ames, lowa. 
and water resources. We must decide how we best meet the needs of an industry relying on large amounts of crop residues as a feedstock source, an investment community relying on large amounts of residue for fuel production and profitability, and soil and water resources relying on these same residues to limit soil erosion and maintain soil carbon levels. Conventional agricultural systems, in the absence of residue removal, have soil erosion rates more than one order of magnitude greater than soil renewal rates (Montgomery 2007), a loss rate clearly that cannot last indefinitely and a rate that science suggests will increase if residues are removed without management adjustments. Soil organic carbon contents, strongly influenced by organic material additions to the soil, have dropped as much as $50 \%$ from levels prior to cultivation in this country (Schlesinger 1985).

This paper addresses cellulosic biofuel system components and their interactions that both directly and indirectly affect soil and water resources. The primary focus will be on identifying critical factors affecting waterinduced soil erosion, soil carbon maintenance, and water quality in the emerging cellulosic bioenergy industry.

\section{Soil Erosion}

Soil is the foundation for plant production. This "foundation" varies across the landscape, and its properties largely determine crop growth and production potential. The thickness of the A horizon, the nutrient and organic matter-rich top layer, is directly related to crop yield potential for corn. This relationship is increasingly sensitive to changes in the A horizon depth, when the depth of this layer is reduced to less than about $25 \mathrm{~cm}$ (10 in) in thickness (Pierce et al. 1984; Craft et al. 1992). Figure 1 illustrates the reduced corn grain yield observed as topsoil depth of loess and glacial till-derived soils in Iowa decreases. The rate of yield decline caused by thinning topsoil varies between soil types, but the trend is consistent between soils. We must also be aware that soil depth impacts on crop yield are dependent on weather and other production factors, and in all situations yield reductions may not be observed (Bakkar et al. 2007). The studies already mentioned in this paragraph focused primarily on grain yield. Studies addressing the mass ratio between corn grain yield and stover yield, expressed as the harvest index, suggest grain yield is more sensitive

\section{Figure 1}

Corn yield relationship to thickness of the A horizon in till-derived and loess-derived soils in lowa.

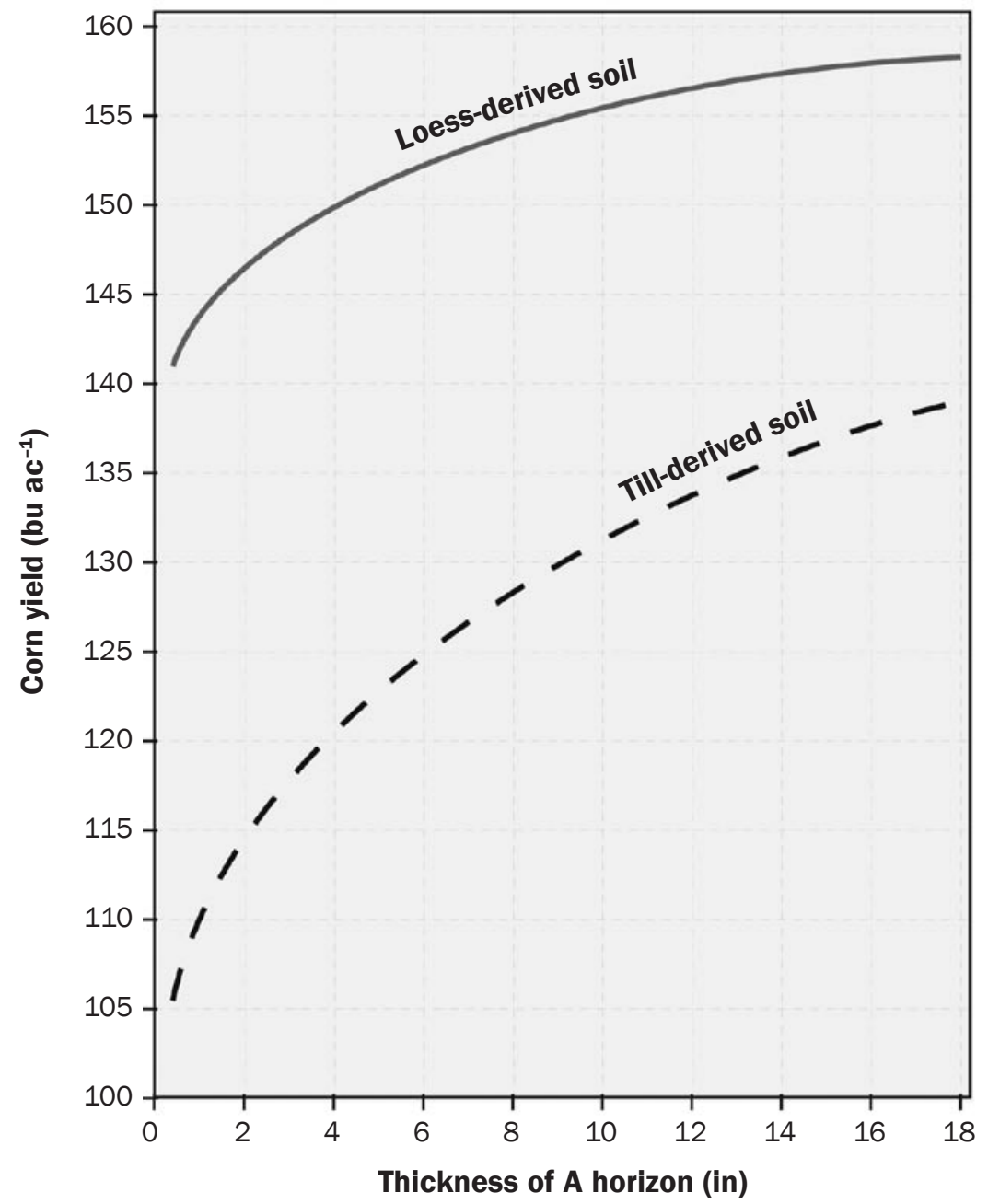

Note: This figure is a modified version of the figure from Kazemi et al. 1990.

to stress than stover yield (DeLougherty and Crookston 1979). However, as stress induces decreased production of one of these components, it also negatively affects the other. Thus, use of the curves in figure 1 to illustrate the potential negative impact of topsoil thinning on stover yield seems warranted, although the rates of change for stover yields will likely differ from that of grain. As topsoil thins, total crop yield potential will decrease in many situations, assuming other factors remain constant. These trends hold for corn, and these general trends will likely occur for other crops with similar rooting depths and water and/or nutrient needs (Hariston and Sanford 1988).

Soil erosion, the movement of soil particles by water or wind, typically thins the topsoil in upland positions, while deposition of these particles increases topsoil depth in selected lower positions on the landscape. Thinning of upland topsoil from erosion-prone positions results in significant yield loss potential (see figure 1), while increasing topsoil depth in the depositional positions that typically already have relatively deep topsoil has considerably less impact on yield.Thus, the net effect of soil erosion is reduced production potential. Soil erosion must be minimized, i.e., topsoil depth must be maintained across the field and landscape if we are to meet the elevated biomass production needs of this industry.

Biomass removal, required for the cellulosic industry, accelerates the soil erosion process, especially for row crops such as corn (Nelson 2002; USDA NRCS Soil Quality National 


\section{Figure 2}

Effect of residue cover on soil erosion expressed as a percent of erosion occurring on a bare, residue-free surface.

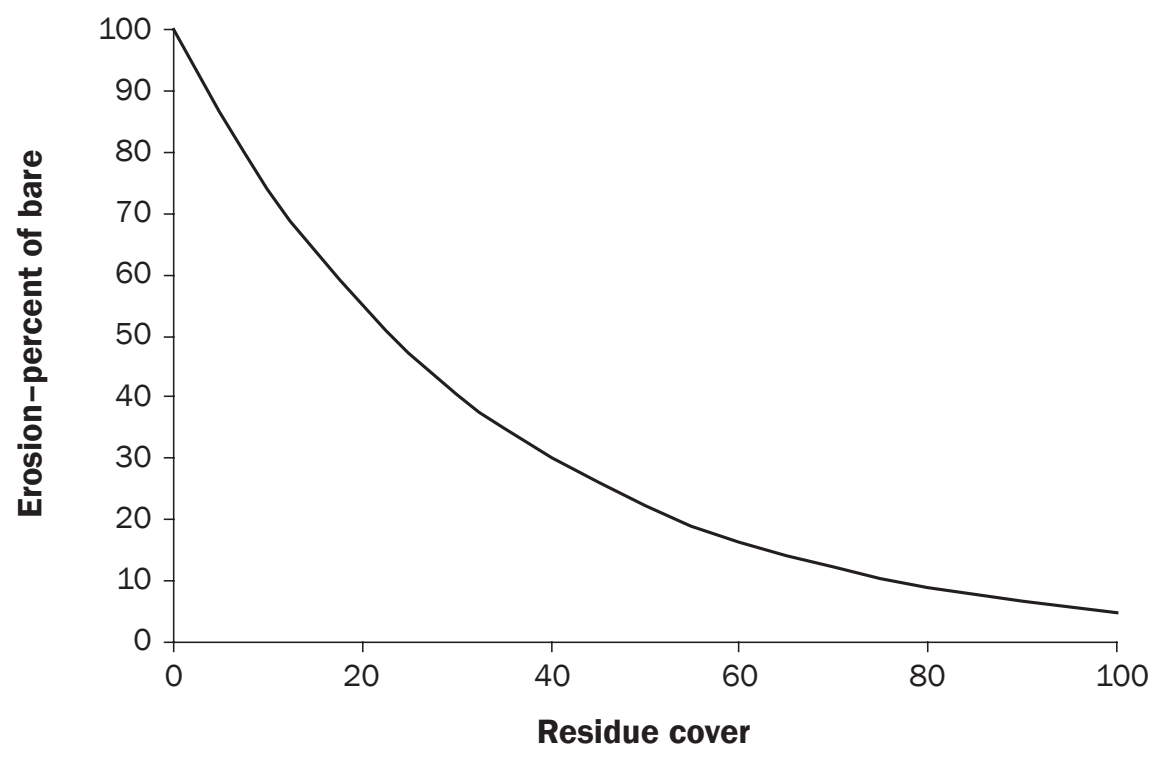

Note: This figure was created using data generated from the Laflen and Colvin (1981) paper.

Technology Development Team 2006). Because soil erosion depends on soil slope and length, among other factors, (Wischmeier and Smith 1978), the impact of residue removal on soil erosion is not quantitatively consistent across the landscape. While generic and simplified, a form of the exponential relationship between residue cover and soil erosion developed by Laflen and Colvin (1981) and given in figure 2 , illustrates that reducing residue cover on a given slope increases soil erosion and that changes in residue cover have a greater impact as residue cover decreases. Residue impacts on soil loss during the soil thawing/snow melt period seem even more critical, especially in highly erosive conditions (Cruse et al. 2001). In the absence of conservation practices such as the use of cover crops, biomass harvest will reduce residue cover and accelerate soil erosion. In order to develop a sustainable cellulosic ethanol industry while maximizing profit, we must (1) have the ability to identify acceptable spatially variable removal rates across the landscape, (2) have harvest technology that removes residue at these rates, (3) maintain the ethics to remove only allowable residue amounts, and (4) be able to manage the remaining residue to minimize soil erosion loss.

\section{Soil Organic Matter}

Soil organic matter (SOM) plays critical roles in both crop production and carbon seques- tration (Sparling et al. 2006; Wilhelm et al. 2007). Cropping practices that reduce SOM will result in reduced soil quality and productivity as well as elevated $\mathrm{CO}_{2}$ emissions. Practices that typically lead to the loss of SOM include, but are not limited to, increasing tillage intensity (USDA NRCS Soil Quality Institute 2003; Simard et al. 1994), management leading to greater soil erosion (USDA NRCS Soil Quality Institute 2003), and/or reduced input of organic materials to the soil (Wilhelm et al. 2007). Of these three management practices, the cellulosic biofuel industry can directly affect two-soil erosion and input of organic materials to soil.

Perlak et al. (2005) indicate that corn residues will be the single biggest crop residue feedstock for the cellulosic industry. Should this materialize, it becomes absolutely critical that we understand how much of this residue can be removed before SOM is jeopardized, and we must understand how sustainable rates of residue removal change across the landscape as slope, soil depth, and soil type change. In other words, precision harvest-matching harvest amounts spatially with a variable soil resource-will likely be required in order to maximize residue harvest while minimizing SOM degradation (Delgado and Berry 2008). Recent literature suggests that, in general, the residue quantities required to maintain soil organic matter are greater than the residue quantities required for soil erosion control (Wilhelm 2007). In other words, restricting residue harvest to insure that SOM is maintained will constrain corn residue harvest beyond that for soil erosion control in many landscape positions. Furthermore, developing spatially variable harvest management techniques requires that we also determine acceptable removal rates for both soil carbon and soil erosion considerations because the crucial factor that limits harvest quantities will likely change with landscape position.

\section{Water Quality}

Nitrogen $(\mathrm{N})$, phosphorus $(\mathrm{P})$, and sediment are the dominant concerns relative to nonpoint source contaminants of surface waters; nitrogen is the dominant nutrient concern for groundwater quality. The Gulf of Mexico hypoxia science consistently targets $\mathrm{N}$ and $\mathrm{P}$ as the primary causes of an enlarged hypoxic zone in the northern Gulf of Mexico (Burkart and James 1999; Alexander et al. 2008). Nitrogen and phosphorus differ in solubility and mobility in water. Perhaps ironically, the most readily available form of $\mathrm{N}$ for crop uptake, $\mathrm{NO}_{3}^{-}$, is also the most mobile form of the nutrient. Phosphorus, on the other hand, has limited water solubility and moves primarily with soil sediment. These basic differences affect management strategies for controlling loss of each. For both, however, reducing load or fertilizer/manure application rates and increasing uptake by plants are critical for protecting water quality. As $\mathrm{N}$ fertilizer application rates increase, nitrate movement through the soil profile increases (Jaynes et al. 2001). If this water is intercepted by tile drains, upon discharge it affects surface water nitrate concentration. If movement downward through the profile continues, it may impact groundwater nitrate concentrations. Reducing P loading of surface waters, on the other hand, depends on reducing nutrient-rich sediment entering these waters. Management strategies that reduce nutrient application rates, increase nutrient uptake, and/or limit sediment delivery are key to limiting surface water degradation (Sharpley et al. 2003).

Recommended $\mathrm{N}$ application rates vary considerably between potential cellulosic feedstocks. Nitrogen application rates vary between states for a given crop, but in general, recommendations for corn are about twice that for switchgrass (Panicum virgatum) to be used as biofuel feedstock 


\section{Table 1}

Average annual RUSLE cropping factor (C) values and average annual weight of surface crop residues for three different corn production systems and switchgrass at two lowa locations. The values of $C$ and post-harvest surface residue weights were obtained from the crop and livestock production and biomass planning tool I-FARM (van Ouwerkerk et al. 2007), which developed soil erosion estimates from USDA ARS (1997).

\begin{tabular}{|c|c|c|c|c|c|c|c|}
\hline \multirow[b]{2}{*}{ Location } & \multicolumn{4}{|l|}{ C } & \multicolumn{3}{|c|}{ Surface residue after harvest $\left(\mathrm{Ib} \mathrm{ac}^{-1}\right)$} \\
\hline & $\begin{array}{l}\text { Corn grain } \\
\text { only }\end{array}$ & $\begin{array}{l}\text { Corn grain } \\
\text { and stover } \\
\text { baled }\end{array}$ & $\begin{array}{l}\text { Corn grain } \\
\text { and stover, } \\
\text { one-pass harvest }\end{array}$ & Switchgrass & $\begin{array}{l}\text { Corn grain } \\
\text { only }\end{array}$ & $\begin{array}{l}\text { Corn grain } \\
\text { and stover } \\
\text { baled }\end{array}$ & $\begin{array}{l}\text { Corn grain } \\
\text { and stover, } \\
\text { one-pass harvest }\end{array}$ \\
\hline Northwest lowa & 0.03 & 0.10 & 0.53 & 0.02 & 5,774 & 2,309 & 289 \\
\hline Central lowa & 0.03 & 0.07 & 0.49 & 0.02 & 6,651 & 2,924 & 366 \\
\hline
\end{tabular}

(Rinehart 2006; Teel et al. 2003; Elbersen et al. 2004; Vogel et al. 2002; Vitosh et al. 1995; Blackmer et al. 1997). Hybrid poplar nutrient recommendations differ from others in that applications are based on tissue tests, at least in selected states (Hansen et al. 1993), and typical application rates are lower than for either corn or switchgrass. Limited data suggests polycultures may require little nutrient application, at least for $\mathrm{N}$ (Tillman et al. 2006). It is more difficult to draw similar conclusions regarding required $\mathrm{P}$ application rates, and therefore potential impact on water quality, because application rates vary based on soil tests and the delivery of $\mathrm{P}$ to surface water is more complex than that for N. Phosphorus application rates cannot be generalized for a given crop as is typically done for N. In general, however, crops respond to increasing soil $\mathrm{P}$ concentrations up to a given level, after which further additions of $\mathrm{P}$ have little yield effect but can affect the quality of water leaving the field. Because P moves primarily with soil sediment, soil erosion and sediment nutrient content are primary indicators of $\mathrm{P}$ delivery to surface water (Sharpley et al. 2003).

Soil erosion is but one step in the sediment delivery process, and drawing water quality inferences for $\mathrm{P}$ and sediment based only on erosion potential requires caution. However, erosion is a direct indication of sediment and sediment-borne nutrients being moved lower on the landscape and/or toward surface water bodies. In situations where eroded sediment can be delivered to surface waters, reducing erosion will reduce delivery of sediment and nutrients carried with them. Thus, a direct indication of cropping system effects on soil erosion should provide a general characterization of the potential impacts of different biomass systems on phosphorus and sediment impacts on surface water.

The Revised Universal Soil Loss Equation (RUSLE) is a multiplicative equation, in which the soil erosion loss estimate depends on multiple variables (Renard et al. 1997).
The "C" factor used in RUSLE gives a direct indication of a cropping system's impact on soil erosion potential. In general, the higher the $\mathrm{C}$ value, the greater is the soil erosion potential of the biomass cropping system. Because RUSLE is a multiplicative equation, other variables such as slope and slope length are also important. Thus, if one variable has a very small value such as would occur for a very short or very gentle slope, predicted erosion rates would be small even for a cropping system with a high $\mathrm{C}$ factor. Furthermore, the value of $\mathrm{C}$ changes during the season based on surface and crop condition changes through time. Despite these precautions in using an annual average $\mathrm{C}$ alone to make statements regarding soil erosion losses, it provides a tool for comparing the erosion potential of different biomass cropping systems when all other factors in the RUSLE remain constant, and therefore, it is an indication of potential impacts on water quality. Values of the $\mathrm{C}$ factor for several cropping systems are given in table 1 for two Iowa locations. In both Central Iowa and Northwestern Iowa, the $\mathrm{C}$ values associated with biomass systems that remove corn stover are much higher than either corn grain only or switchgrass. This suggests that cellulosic biomass production that depends on removing corn residue, compared to switchgrass for example, from fields substantially increases sediment movement and the potential phosphorus delivery to surface water and thus increases the threat to water quality both at the farm edge and in receiving surface waters.

\section{Rainfall Patterns}

High energy storms coupled with high intensity rainfall cause a disproportionate amount of soil erosion for the amount of precipitation delivered (SWCS 2003; Laflen et al. 2004; Ghidey and Alberts 1996). Model projections of increased frequency of extreme rainfall events (IPCC 2007) along with observations supporting these model projections (Groisman et al. 2005; IPCC 2007) strongly suggest soil surface cover removal for any purpose needs careful consideration. The study by Groisman et al. (2005) clearly showed that the frequency of intense daily rainfall events has been increasing in the Central United States since about 1970. In the 32-year period following 1970 , frequency of these events increased about 26\%. The Central United States is expected to be a major provider of liquid fuel feedstocks through harvested corn residues. Additionally, this area is already targeted as a major contributor to the Northern Gulf of Mexico hypoxia (USEPA 2007), and increasing runoff and soil loss would only add to this challenge. To keep soil loss, water runoff, and associated nutrient loss at an acceptable level as intense rain events increase, innovative cropping practices integrating, for example, cover crops and/or perennial species with row crops in areas sensitive to soil and water loss must be implemented.

\section{Land Management}

The long-term profitability of producers and of the cellulosic ethanol industry requires that we sustain the resource base upon which production relies - in this case soil and water. Conversely, short term profits for producers and processors will likely be increased by practices unfavorable to these resources, namely maximizing the amount of crop residue removed and sold. Because plant residue plays a critical role in sustaining soil and water resources, it is critical that we balance shortterm profits associated with residue removal and long-term production stability and profitability associated with residue cover. The current system of land management and land rental patterns, however, makes it difficult to achieve this balance.

A substantial amount of harvested lands in the United States is rented, and in agriculturally dominated states, the percentage of harvested lands that are rented is frequently over 50\% (USDA NASS 2002). Increasingly, 
the rental agreement involves cash rent (Duffy 2004) at least in Iowa. Limited evidence indicates that in a majority of situations, renters are the sole decision makers relative to management decisions (Tom Buman personal communication 2008). Combined, these trends discourage sustainable land management practices. As stated in the Millennium Ecosystems Assessment Report (2005), "When farmers and herders lose control of long-term security over the land they use, the incentives for maintaining environmentally sustainable practices are lost." In the context of the cellulosic ethanol industry, these land management situations present three challenges to balancing long and short term benefits and to establishing sustainable practices. First, management practices proven to conserve soil and water such as use of selected crop rotations, cover cropping, and establishment of dedicated perennials for biomass require management and land control for multiple years. Unless a farmer has control of land (s)he manages for multiple years or unless the land owner increasingly plays a role in management decisions, the opportunities to utilize a suite of conservation practices that extend over multiple years to offset impacts of residue harvest on soil and water resources are limited at best. For this reason short term, especially annual, land leases discourage conservation practices that conserve soil and water. A second challenge to long term sustainability of soil and water resources occurs because the marketplace and world food/feed demand encourages producers to plant corn on increasingly larger land areas. Where crop rotations have previously been practiced, high corn prices encourage continuous corn on more land areas. As an annual crop, corn fits nicely into short term rental lease arrangements and is a highly demanded crop commodity. This row crop, however, with residue harvested for feedstock, presents greater water runoff, water quality, and soil erosion challenges than would dedicated perennials such as switchgrass (see table 1). Finally, the long-term benefits associated with leaving sufficient residue cover to sustain soil and water resources are in conflict with short term profit motives associated with short-term leases. Expecting a renter to sacrifice income without other benefits associated with maintaining residue cover to sustain the soil and water resource base seems somewhat unrealistic unless his/ her landlord compensates for such manage- ment decisions or restricts residue removal. Developing a government program to compensate producers for leaving residue in the field rather than removing and selling it for liquid fuel production also seems challenging and very expensive, both in terms of direct payments to producers and loss of fossil fuel replacement. Alternatively, while penalties might be invoked for excessive residue harvest, this raises two critical difficulties: (1) how will decisions be made regarding allowable harvest quantities - do we have the science to identify allowable removal rates spatially on the landscape, and (2) who will monitor residue removal (or surface residue cover after harvest) and police such a program? This approach also would become very expensive. Fully understanding that owner control over land management decisions does not guarantee wise management decisions, in the absence of long-term interest in the land being farmed, incentives and benefits associated with soil and water conservation in the emerging cellulosic bioeconomy are limited.

\section{Summary and Conclusions}

Any one of the above challenges seems formidable relative to soil and water conservation in the emerging cellulosic bioeconomy. Collectively, the challenge is amplified. The need to replace large volumes of petroleumbased fuels will likely create a large demand for plant biomass. The market demand for corn grain will likely result in continued production of this row crop on large land areas with corn residue being used to meet the increasing demand for cellulosic feedstocks. Financial investments in the industry will increase pressure to produce and deliver large volumes of cellulosic feedstocks to conversion facilities. Financial incentives for residue removal will likely be much greater than the financial incentives to leave residues on the land to protect soil and water resources.

To add to this dilemma, producers who rent the land they farm have short-term profit interests in the rented land from which they will have the opportunity to harvest biomass. The short-term profit interest and short-term control of rented land makes production of annual row crops most feasible. The crop most suitable for existing short-term rental conditions, that offers the greatest short-term income, and that seemingly will meet the needs of the cellulosic biofuel industry is corn. Unfortunately, this is also the potential biomass feedstock crop requiring the highest $\mathrm{N}$ application rates, a significant water quality concern. Row crops, when residue is removed, create a land surface more vulnerable to soil erosion than that occurring for harvest of dedicated perennial species such as switchgrass. Climate change patterns, both predicted and observed, are creating more high-intensity rainfall events with the potential to elevate soil erosion loss rates and elevate phosphorus levels found in surface waters. Recent literature suggests residue removal rates to maintain soil organic matter, especially for row crops, are even lower than those necessary for soil erosion control.

Under the conditions described, the need to develop incentives to limit residue removal on row-cropped land or to use a suite of conservation practices with row-crop production seems apparent. Because crops such as perennial grasses and even trees may have a market in the cellulosic biofuel industry, spatial management and use of these species on particularly sensitive areas should meet less producer resistance than in the past. It is very important to determine location of these sensitive areas and to establish perennials as soon as possible to minimize environmental impacts of annual row cropping coupled with biomass removal.

Conserving soil and water resources as the cellulosic biofuel industry develops is crucial to the sustainability of the industry and to protecting the land management options available to future generations. Removal of too much cellulose materials will increase future food production costs, lower production potential, and aggravate world hunger problems. Research to advance conservation of soil and water resources should determine more precisely the erosion and sediment delivery rates of different biomass cropping systems, determine the acceptable rates of residue removal for different crops and soils, describe how those acceptable removal rates vary spatially across the landscape, and develop the harvest technology that removes residue at these rates. Policy analysis should examine land ownership and management patterns to develop a policy environment in which conservation practices are encouraged, or at least not discouraged. A framework must be developed to oversee and insure that the profit motive associated with residue sales 
does not result in residue removal rates abusive to soil and water resources.

\section{Acknowledgements}

Research Editorial paper was presented at the 8th Joint Soil Science Society of America and SWCS annual symposium (2007).

\section{References}

Alexander, R.B., R.A. Smith, G.E. Schwarz, E.W. Boyer, J.V. Nolan, and J. Brakebill. 2008. Differences in phosphorus and nitrogen delivery to the Gulf of Mexico from the Mississippi River Basin. Environmental Science Technology 42(3):822-830.

Bakker, M.M., G. Govers, R.A. Jones, and M.D.A. Rounsevell. 2007. Effect of Europe's erosion on crop yields. Ecosystems 10:1209-1219.

Blackmer,A.M., R.D.Voss, and A.P. Mallarino. 1997. Nitrogen fertilizer recommendations for corn in Iowa. Iowa State University Extension Publication Pm. 1714. Ames, IA Iowa State University.

Burkart, M.R., and D.E. James. 1999. Agricultural-nitrogen contributions to hypoxia in the Gulf of Mexico. Journal of Environmental Quality 28(3):850-859.

Craft, E.M., R.M. Cruse, and G.A. Miller. 1992. Soil erosion effects on corn yields assessed by potential yield index model. Soil Science Society of America Journal 56:878-883.

Cruse, R.M., R. Mier, and C.W. Mize. 2001. Surface residue effects on erosion of thawing soils. Soil Science Society of America Journal 65:178-184

Delgado, J.A., and J.K. Berry. 2008. Advances in Precision Conservation. Journal of Advances in Agronomy 98:1-44.

DeLougherty, R.L., and K. Crookston. 1979. Harvest index of corn affected by population density, maturity rating, and environment. Agronomy Journal 71:577-580.

Duffy, Mike. 2004. Trends in Iowa farmland ownership. Ag Decision Maker, October. http://www.extension.iastate. edu/agdm/articles/duffy/DuffyOct04.htm.

Elbersen, H.W., D.G. Christian, N. El Bassam, G. Sauerbeck, E. Alexopoulou, N. Sharma, and I. Piscioneri. 2004. A management guide for planting and production of switchgrass as a biomass crop in Europe. In Proceedings 2nd World Conference on Biomass for Energy, Industry, and Climate Protection, 140-142. Rome, Italy, May 10-14, 2004

Energy Information Administration. 2008. What are Biofuels and How Much do we Use. http://tonto.eia.doe.gov/ energy_in_brief/biofuels_use.cfm.

Ghidey, F., and E.E. Alberts. 1996. Comparison of measured and WEPP predicted runoff and soil loss for Midwest Claypan soils. Transactions of the American Society of Agricultural Engineers 39:1395-1402.

Groisman, P.Y., R.W. Knight, D.R. Easterling, T.R. Karl, G.C. Hegerl, and V.N. Razuyaey. 2005. Trends in intense precipitation in the climate record. Journal of Climate 18:1326-1350.

Hansen, E.A., D.A. Netzer, and D.N.Tolsted. 1993. Guidelines for Establishing Poplar in the North Central US. USDA Forest Service Research note NC-363.

Hariston, J.E., and J.O. Sanford. 1988. Effect of soil depth and erosion on yield in the Mississippi Blacklands. Soil Science Society of America Journal 52:1458-1463.

Intergovernmental Panel on Climate Change. 2007. Climate Change 2007: Synthesis Report. IPCC Plenary XXVII. Valencia, Spain, November 12-17, 2007.
Jaynes, D.B., T.S. Colvin, D.L. Karlen, C.A. Cambardella, and D.W. Meek. 2001. Nitrate loss in subsurface drainage as affected by nitrogen fertilizer rate. Journal of Environmental Quality 30:1305-1314.

Kazemi, M., L.C. Dumenil, and T.E. Fenton. 1990. Effects of Accelerated Erosion on Corn Yields of Loess-derived and Till-derived Soils in Iowa. Final report for Soil Conservation Service Agreement No. 68-6114-0-8, Des Moines, IA.

Laflen, J.M., and T.S. Colvin. 1981. Effect of crop residue on soil loss from continuous row cropping. Transactions of the American Society of Agricultural Engineers 24(3):605-609.

Laflen, J.M., D.C. Flanagan, and B.A. Engel. 2004. Soil erosion and sediment yield prediction accuracy using WEPP. Journal of the American Water Resources Association 40:289-297.

Millennium Ecosystem Assessment. 2005. Ecosystems and human well-being: Desertification synthesis. Washington, DC: World Resources Institute.

Montgomery, D.R. 2007. Soil erosion and agricultural sustainability. Proceedings of the National Academy of Sciences 104:13268-13272.

NCGA (National Corn Growers Association). 2007. National Corn Growers Association Annual Report. http:// www.ncga.com/files/pdf/2007AnnualReport.pdf.

Nelson, R.G. 2002. Resource assessment and removal analysis for corn stover and wheat straw in the Eastern and Midwestern United States-rainfall and wind-induced soil erosion methodology. Biomass and Bioenergy 22:349-363.

Perlack, R.D., L.L. Wright, A. Turhollow, R.L. Graham, B. Stokes, and D.C. Urbach. 2005. Biomass as feedstock for bioenergy and bioproducts industry: The technical feasibility of a billion-ton annual supply, prepared for the US Department of Energy and the US Department of Agriculture, ORNL/TM-2005/66. Oak Ridge, TN: Oak Ridge National Laboratory.

Pierce, FJ., W.E. Larson, R.H. Dowdy, and W.A.P. Graham. 1984. Productivity of soils: Assessing long-term change due to erosion. Journal of Soil and Water Conservation 39(2):131-136.

Renard, K.G., G.R. Foster, G.A. Weesies, D.K. McCool, and D.C. Yoder. 1997. Predicting soil erosion by water: A guide to conservation planning with the Revised Universal Soil Loss Equation (RUSLE): Agriculture Handbook.Vol. 703. Tucson (AZ) South West Watershed Research Center, Agricultural Research Service, US Department of Agriculture.

Rinehart, L. 2006. Switchgrass as a bioenergy crop. National Sustainable Agriculture Information Service, ATTRA Publication \#IP302.

Schlesinger, W.H. 1985. Changes in soil carbon storage and associated properties with disturbance an recovery. In The changing carbon cycle: A global analysis, ed. J.R. Trabalha and D.E. Reichle, 194-220. New York: Springer-Verlag.

Sharpley, A.N., T. Daniel, T. Sims, J. Lemunyon, R. Stevens, and R. Parry. 2003. Agricultural Phosphorus and Eutrophication 2nd edition. USDA ARS Report 149. Washington, DC: US Government Printing Office.

Simard, R.R., D.A. Agners, and C. Lapierre. 1994. Soil organic matter quality as influenced by tillage, limie, and phosphorus. Biology and Fertility of Soils 18:13-18.

SWCS (Soil and Water Conservation Society). 2003. Conservation implications of climate change: Soil erosion and runoff from cropland. Ankeny, IA: Soil and Water Conservation Society.
Sparling, G.P., D. Wheeler, E.-T. Vesely, and L.A. Schipper. 2006. What is soil organic matter worth? Journal of Environmental Quality 35(2):548-557.

Teel,A., S. Barnhart, and G. Miller. 2003. Management Guide for the Production of Switchgrass for Biomass Fuel in Southern Iowa. Iowa State University Extension PM 710

Tilman, D., J. Hill, and C. Lehman. 2006. Carbon-negative biofuels from low-input high-diversity grassland biomass. Science 314:1598-1600.

US DOE (Department of Energy) Biomass Technical Advisory Committee. 2002. Vision for Bioenergy \& Biobased Products in the United States. http:// www.climatevision.gov/sectors/electricpower/pdfs/ bioenergy_vision.pdf.

US DOE. 2007. Biofuels for Transportation. http:// genomicsgtl.energy.gov/biofuels/transportation.shtml.

USDA NASS (National Agricultural Statistics Service). 2002 Census of Agriculture. http://www.agcensus.usda.gov/ Publications/2002/Volume_1,_Chapter_2_US_State_ Level/st99_2_040_040.pdf.

USDA NRCS (Natural Resources Conservation Service) Soil Quality Institute. 2003. Managing Soil Organic Matter. The Key to Air and Water Quality. Soil Quality Technical Note No. 5. USDA Natural Resource Conservation Service.

USDA NRCS Soil Quality National Technology Development Team. 2006. Crop Residue Removal for Biomass Energy Production: Effects on Soils and Recommendations. Soil Quality-Technical Note No. 19. USDA Natural Resources Conservation Service.

USEPA (Environmental Protection Agency). 2007. Hypoxia in the Northern Gulf of Mexico. An Update by the EPA Science Advisory Board. EPA-SAB-08-003.

van Ouwerkerk, E.N.J. van, T.L. Richard, and R.P. Anex. 2007. Web based and database driven support tool for integrated farming. On: Farming Systems Design 2007 Int. Symposium on Methodologies on Integrated Analysis on Farm Production Systems, ed. M. Donatelli, J. Hatfield, and A. Rizzoli, 171-172. Catania (Italy) 10-12 September 2007, book 1 - Farm-regional scale design and improvement.

Vitosh, M.L., J.W. Johnson, and D.B. Mengel. 1995. Tri-state fertilizer recommendations for corn, soybeans, wheat, and alfalfa. Extension Bulletin E-2567. E. Lansing, MI: Michigan State University.

Vogel, K.P., J.J. Brejda, D.T. Walters, and D.R. Buxton. 2002 Switchgrass biomass production in the Midwest USA Harvest and nitrogen management. Agronomy Journal 94:413-420.

Wilhelm, W.W., J.M.F. Johnson, D.L. Karlen, and D.T Lightle. 2007. Corn stover to sustain soil organic carbon further constrains biomass supply. Agronomy Journal 99:1665-1667.

Wischmeier, W.H., and D. Smith. 1978. Predicting rainfall erosion losses: A guide to conservation planning. USDA ARS Agriculture Handbook 537, Washington DC: USDA ARS 